\title{
Profit Influential Factors of Women Entrepreneurs' Enterprises: A Case Study in Sylhet City, Bangladesh.
}

\author{
Md. Anowar Hossain ${ }^{1}$, Brazendra Nath Roy ${ }^{2}$ \\ Department of Business Administration, Pundra University of Science \& Technoloy ${ }^{I}$ \\ Department of Business Administration, Pundra University of Science \& Technoloy ${ }^{2}$
}

\begin{abstract}
In recent years, women-owned businesses have experienced rapid growth in certain industries of the world including Bangladesh. Entrepreneurship is an economic activity which is undertaken by an individual or group of individuals. Women are a part of the nation's manpower. This manpower of Bangladesh has already shown its immense potential in different socio-economic sectors. The purpose of the study is to investigate the available support services \& factors those affect the profit earned by female entrepreneurs. In this study, data were collected from different areas in Sylhet City of Bangladesh and used the Pearson's correlation since the questionnaires were employed to collect primary data from the field. The major finding of the study is training, easy finance in start up, family support are the major influential factors those affect profit of women entrepreneur's enterprises. The study also finds specific obstacles to women's entrepreneurship in Sylhet city: type of education, lack of role models in entrepreneurship, gendering of entrepreneurship, weak social status, competing demands on time and access to finance. Based on these findings, policy makers can increase the ability of women to participate in the work place. More generally, improving the contribution of financial institutions will expand benefits in terms of women's entrepreneurship in Sylhet city as well as in Bangladesh.

Keywords: Manpower, Weak Social Status. Women-Entrepreneurship.
\end{abstract}

\section{Introduction}

Bangladesh is resource limited overpopulated country. Here the contributions of women are not acknowledged in society especially in rural areas of country. In some cases they are deprived of social value too. Since the inception of the idea of self employment, women started creating their employment. The traditional idea of women's role as only bearing and rearing of children is now a myth. They now perform as income earning member along with others family responsibility. Women are now turning their role as also income earning person in family, taking part in economic development with self employment too. When a female person starts or organizes and manages any business with rationale level of risk then she is referred as a female entrepreneur. Women entrepreneur is any women who organizes and manages any enterprise, especially a business. According to Global Entrepreneurship Monitor (GEM) currently 126 million women are in start up businesses, and 98 million are already operating established business with three and half years. Saxena, A. $(2016)^{[1]}$. Women Entrepreneurship Index (WEI) 2015 finds the numbers of female entrepreneurship is increasing throughout the world ${ }^{[2]}$. Total of 6.5 million businesses were mostly owned by female in the world.

\section{Literature Review}

Begum (1993) stated that before 1985, Bangladesh had very few women entrepreneurs ${ }^{[3]}$. Another study also shows that the number of women entrepreneurs is around 3000, representing only $2 \%$ of the total entrepreneurs in the country, although women constitute about 50\% of the population (Ahmed, 2003) ${ }^{[4]}$. Women entrepreneurs have a special role to play in creating empowerment and establishing entitlement in every sphere of socioeconomic advancement (Choudhury, Hossain \& Solaiman, 2008) ${ }^{[5]}$. The emergence of women entrepreneurs in a society depends mainly on economic, social, religious, cultural and psychological factors (Habibet.al., 2005) ${ }^{[6]}$. Chandra \& Arora (2013) finds 74 out of every one hundred women entrepreneurs face financial problem not excluding problem of subsidy and assistance from government ${ }^{[7]}$. Women face unique obstacles in starting and growing their firms such as lack of skill or training, lack of easy access to capital or credit, lack of savings and social networks, and limited choice of industry (Ibru, 2009; Lakwo, 2007;Ojo, 2009) $[8,9,10]$

In fact, women entrepreneurship development is a challenging phenomenon in Bangladesh as women are lagged behind (economically and socially) compared to men (Haque and Itohara, 2009) ${ }^{[11]}$. Generally, women are more victimized as because of their illiteracy, unawareness, unorganized, powerless or less political representation, deprivation, rigid social customs, religious constrains and injustice by their counter partners particularly in rural areas (Chowdhury, $2000^{[12]}$; Afrin et al., 2008) ${ }^{[13]}$. Huda (2009) examine women entrepreneurs of Bangladeshi by taking both formal and informal sector of economy and have growing interest of them to extend their business commercially ${ }^{[14]}$. 
Third world country like Bangladesh women in power and access in taking decisions has increased than before in household and economic matters, which has made them more autarky than previous time. Besides, political participation is the important indicator which is not widely seen among Bangladeshi women entrepreneurs (Nawaz 2010) ${ }^{[15]}$. In this context the development of beauty parlor industry in Bangladesh flourishes silently. According to the recent studies, it is suggested that the beauty salon industry is worth around BDT10 billion and it is growing each day. Creation of self employment and generation of revenue have been contributed by this sector (IDLC, 2014) ${ }^{[16]}$.

\section{Statement Of The Problem}

Review of associated literature it's obvious to researcher that though female entrepreneurs are increasing but it needs more fosterers which would bring a dynamic change in the style. Here the problem of research is stated as how selected factors (micro-finance) removes barriers of female entrepreneurship and enhances profitability. As previous research has shown the significance of finance in fostering entrepreneurship, so this study will focus on finding out the leveraging effect of some selected factors on profitability of women entrepreneurs in Sylhet City.

\section{Research Questions}

Review of literature has revealed number of factors related to women entrepreneurship. Some of those are related to socio-cultural \& religious and some are related to finance. While in start-up stage, venture needs more easy way of finance but they lack it for being female in gender (Chandar \& Arora 2003). Banking and Non-banking financial institutions show their own logic of greater probability of moving from one place to another by women. Hence, in this study it is tried to form some questions like;

$\circ \quad$ Is there any dependency between starting amount of capital and profit?

○ How other factors like; education, training, family support enhance the profit potential of women entrepreneurs.

\section{Research Objective}

Specification of the problems, it's now clear about the objectives which would be focused. According to the design and nature of the study; objectives are categorized into two basic classes.

Broad Objective: The broad objective of the study is to know the forces of micro-finance on profitability of women entrepreneur's enterprise.

There are some other supportive objectives which will enhance the deepness of the study are as follows;

- To determine the other related variables for which profit of women entrepreneurs may vary.

○ To know about easy \& supportive source of finance for women entrepreneurs.

\section{Methodology}

Sample Size \& Technique: Due to lack of availability of list of business owned by women the study needed to focus on available source. Available sample size is determined on basis of women entrepreneurs only doing their business in City area that confined the size to be fifty (50). In determining the size of sample purposive sampling technique is used as here this strategy is seemed suitable on basis of nature of source of data. After preparing the questionnaire every respondents of the sample was interviewed and requested to put a tick mark on option of questionnaire.

Data Source: This study is conducted on purely basis of primary data. The nature of study requires only selected source which is female business owner in Sylhet City. But finding out number of women entrepreneurship in City requires a list which has been done through visiting to every business owned by female. At every stage of data collection, priority was given to objectives. The study tries to explore actual conditions of some variables and relationship with profit of women enterprise.

Primary Source: Includes field survey with semi-structured questionnaire. After having the list of female business owner in Sylhet City every respondent are visited with questionnaire and information are collected. The design of questionnaire includes qualitative data like satisfied or not and interested to reinvest or not along with quantitative data to better serve the purpose of the study.

Techniques of Analysis: For clear comparison of variables initially tabular analyses were used. This was used to find out the association or difference between variables. Tabulated data were analyzed by using various descriptive statistical tools like mean, median, mode, correlation analysis \& Chi-square test.

Software: SPSS. 
VII. Analysis Of Data

Cross-Tabulation (Sources of Capital * Current Rate of Profit)

\begin{tabular}{|l|l|l|l|l|l|l|}
\hline \multicolumn{2}{|c|}{} & \multicolumn{2}{l|}{ current rate of profit } & & \\
\multicolumn{2}{|l|}{} & $0-5 \%$ & $6-10$ & $11-15$ & $16-25$ & Total \\
\hline Sources of & Savings & 7 & 4 & 0 & 0 & 11 \\
capital & Loan & 0 & 0 & 1 & 0 & 1 \\
& savings and loan & 2 & 6 & 8 & 3 & 19 \\
Total & Family & 7 & 7 & 4 & 1 & 19 \\
\end{tabular}

Table-01: relational dependency between source of capital and current profit.

Tabulated data shows a critical point of source of financing in which female enterprise those takes loans can rarely earn a profit. Only one respondent is found to earn 11 to 15 percents profit who has taken loan from any financial institutions. Total 11 female entrepreneurs have set their venture with own savings and 7 female enterprise earned 0 to 5\%, 4 earned 6 to 10 percent. Most succeeding part covers those who are in the segments of using loan and savings as sources of capital. Another mentionable category is family in which total 19 businesses earned profit on attractive level.

Chi-Square Tests

\begin{tabular}{|l|l|l|l|}
\hline & Value & Df & Asymp.Sig. (2-sided) \\
\hline Pearson Chi-Square & $16.693(\mathrm{a})$ & 9 & .054 \\
Likelihood Ratio & 19.885 & 9 & .019 \\
Linear-by-Linear Association & 2.659 & 1 & .103 \\
N of Valid Cases & 50 & & \\
\hline
\end{tabular}

The result of chi square test sows a weak but not negligible dependency of current rate of profit on source of capital. A chi-square value of .054 indicates there is a positive relation or dependency between source of capital and rate of profit. Two tailed test of chi square generating value 0.054 shows relatively strong relations.

Cross Tabulation: Starting Amount * Current Rate of Profit

\begin{tabular}{|ll|l|l|l|l|l|}
\hline \multicolumn{2}{|l|}{} & \multicolumn{2}{l|}{ current rate of profit } & \multicolumn{2}{l|}{ Total } \\
\hline Starting & $20000-50000$ & $0-5 \%$ & $6-10$ & $11-15$ & $16-25$ & \\
amount & & 8 & 3 & 1 & 0 & 12 \\
& $50001-100000$ & 5 & 2 & 1 & 0 & 8 \\
& $100001-1000000$ & 3 & 12 & 10 & 4 & 29 \\
Total & 1000001 -above & 0 & 0 & 1 & 0 & 1 \\
\end{tabular}

Table-02: Starting amount of capital \& rate of profit.

The tabular data shows while the class of business with initial capital of 20000 to 50000,8 businesses earn up-to 5\%, 3 businesses earns $6-10 \%$ and only one business earns $11-15 \%$. Second category of business those starts their business with 50001 to 100000 taka; 5 earns up-to 5\%, 2 earns 6 to $10 \%$, one business earns 11 to $15 \%$. While business with higher amount of initial capital (100001 to 1000000) earns more profit than any business with less amount of initial capital. Up-to $5 \%$ is by 3, 6-10 by 12, 11-15 by 10 and 16-25 by 4 businesses covering maximum number of business 29 out of total 50 .

\begin{tabular}{|l|l|l|l|}
\multicolumn{5}{|c|}{ Chi-Square Tests } \\
\hline Pearson Chi-Square & Value & Df & Asymp. Sig. (2-sided) \\
Likelihood Ratio & $20.490(a)$ & 9 & .015 \\
Linear-by-Linear & 22.260 & 9 & .008 \\
Association & 14.235 & 1 & .000 \\
N of Valid Cases & 50 & & \\
\hline
\end{tabular}

The chi square value is 0.015 which is smaller than 0.50 . There is strongly significant relation of dependency between start-up capital and rate of profit. The summery of analysis shows strongly significant relations between amount of capital and rate of profit earned by women owned business. Reasoning may be said as for higher initial cost of setting a business, female entrepreneurs need to have bigger amount of capital. If they lacks this then it becomes hard to earn higher profit on their venture. 
Profit Influential Factors of Women Entrepreneurs' Enterprises: A Case Study in Sylhet City,

Cross Tabulation: Duration of Business * Current Rate of Profit

\begin{tabular}{|c|c|c|c|c|c|c|}
\hline & & \multicolumn{4}{|c|}{ current rate of profit } & \multirow[b]{2}{*}{ Total } \\
\hline & & $0-5 \%$ & $6-10$ & $11-15$ & $16-25$ & \\
\hline \multirow{3}{*}{$\begin{array}{l}\text { Duration } \\
\text { Business }\end{array}$} & 1-5 Years & $\overline{8}$ & 5 & 8 & 4 & 25 \\
\hline & $6-10$ & 8 & 10 & 1 & 0 & 19 \\
\hline & $11-15$ & 0 & 2 & 4 & 0 & 6 \\
\hline \multicolumn{2}{|l|}{ Total } & 16 & 17 & 13 & 4 & 50 \\
\hline
\end{tabular}

Table-3: Duration of business and current rate of profit.

The result shows 0 to $5 \%$ profit is earned by 8 women entrepreneurs, $6-10 \%$ by 5 businesses, $11-15 \%$ by 8 and $16-25 \%$ by 4 businesses which falls under the class of 1-5 years of duration of business. Again the business which are categorized in class of 6 to 10 years of duration, 8 enterprise earn 0 to $5 \%, 10$ enterprise earn 6 to $10 \%$ only 1 enterprise earn 11 to $15 \%$ profit. Profit of business with age duration of 11 to 15 years or more is $6-10 \%$ by 2 and $11-15 \%$ by 4 businesses. This is a clear point here which seems there is no more business with 11 to 15 years or more. Which indicates that the idea of female entrepreneurship is not exercised in practice long before at the research area. Still point of optimism is here are some businesses which have been running under the ownership of female with so long duration.

Chi-Square Tests

\begin{tabular}{|l|l|l|l|}
\hline & Value & Df & Asymp. Sig. (2-sided) \\
\hline Pearson Chi-Square & $17.213(\mathrm{a})$ & 6 & .009 \\
Likelihood Ratio & 20.950 & 6 & .002 \\
Linear-by-Linear Association & .204 & 1 & .651 \\
N of Valid Cases & 50 & & \\
\hline
\end{tabular}

Analyzed data shows the value of chi square to be strongly significant as because 0.009 is much more less than 0.05 . This indicates a strong relation and dependency between this two. As the business continues it's operation for longer time they becomes efficient hence profitability increases at higher rate. Analysis of collected data shows a statistically significant relation. (Value of chi-square is .009).

Cross tabulation: Education Level * Current Rate of Profit

\begin{tabular}{|ll|l|l|l|l|l|}
\hline & \multicolumn{2}{l|}{ current rate of profit } & \multicolumn{2}{l|}{ Total } \\
\hline & & $0-5 \%$ & $6-10$ & $11-15$ & $16-25$ & \\
\hline Educational Level & Below Graduation & 13 & 14 & 6 & 2 & 35 \\
& Above Graduation & 3 & 2 & 2 & 1 & 8 \\
Total & Graduation & 0 & 1 & 5 & 1 & 7 \\
\end{tabular}

Table-04: level of education and current rate of profit.

The value of above table clearly shows that with even low education females are more profit than females with higher education. Maximum numbers of females (35 out of total 50) are with below graduation earning profit on their ventures. The entrepreneurs with only graduation covers 7 who are on profit earning class of various percentages. Slightly more positive sign is women with more than graduation degrees earn comparatively more profit.

Chi-Square Tests

\begin{tabular}{|l|l|l|l|}
\hline & Value & Df & Asymp. Sig. (2-sided) \\
\hline Pearson Chi-Square & $11.358(a)$ & 6 & .078 \\
Likelihood Ratio & 12.070 & 6 & .060 \\
Linear-by-Linear & 6.854 & 1 & .009 \\
Association & 50 & & \\
N of Valid Cases & & & \\
\hline
\end{tabular}

The previous tabular data and relative theoretical analysis though shows a signal of higher degree women earns more profit but female with below graduation also earns profit and number of this category is maximum. Result of test of dependency shows a non significant relationship between level of education and rate of profit earned by female owned business. Which is clear from chi square value of 0.078 which is higher than 0.05 to be significant. 
Profit Influential Factors of Women Entrepreneurs' Enterprises: A Case Study in Sylhet City,

Cross-Tabulation: Taken any Training or Not * Current Rate of Profit

\begin{tabular}{|ll|l|l|l|l|l|}
\hline \multicolumn{5}{|l|l|l|}{ current rate of profit } & Total \\
\hline & & $0-5 \%$ & $6-10$ & $11-15$ & $16-25$ & \\
\hline taken any training or not & Yes & 10 & 4 & 10 & 3 & 27 \\
& No & 6 & 13 & 3 & 1 & 23 \\
Total & 16 & 17 & 13 & 4 & 50 \\
\hline
\end{tabular}

Table-05: Relational dependency of training and rate of profit.

Data of table basically shows a form of relation like, while 27 numbers of female businesses earn profit with training some others 23 earns profit without training. Critical point here is more women (10) with training earn higher rate of profit (11-15\%) than (3) without training. But thing is not same for less rate of profit. In profit category of 6 to $10 \%$, number of female business without training earns more profit (13) than numbers (4) women entrepreneurs with training.

\section{Chi-Square Tests}

\begin{tabular}{|l|l|l|l|}
\hline & Value & df & Asymp. Sig. (2-sided) \\
\hline Pearson Chi-Square & $10.280(\mathrm{a})$ & 3 & .016 \\
Likelihood Ratio & 10.730 & 3 & .013 \\
Linear-by-Linear Association & .965 & 1 & .326 \\
N of Valid Cases & 50 & & \\
\hline
\end{tabular}

The relation between training and rate of profit is strongly significant. Which means rate of profit depends upon the training of women entrepreneurs. Entrepreneurs with technical training can make good contact with forward and backward linkage and can provide better services than others.

\section{Cross-Tabulation: Family Support or Not * Satisfaction with Current Rate of Profit}

\begin{tabular}{|ll|l|l|l|}
\hline \multicolumn{4}{|l|}{ Satisfaction with current rate of profit } & Total \\
\hline & Yes & No & \\
\hline family support or not & yes & 33 & 12 & 45 \\
& no & 5 & 0 & 5 \\
Total & 38 & 12 & 50 \\
\hline
\end{tabular}

Table-06: Dependency of current profit on family support.

Analyzed listed tabular data signifies that being helped by family support 33 numbers of female entrepreneurs is satisfied with their current rate of profit while 12 are not. Another 10 percent of female entrepreneurs are not helped by family support. Here it's clear that if females get family support then they get satisfaction with their profit.

\section{Chi-Square Tests}

\begin{tabular}{|c|c|c|c|c|c|}
\hline & Value & Df & $\begin{array}{l}\begin{array}{l}\text { Asymp. } \\
\text { sided })\end{array} \\
\end{array}$ & $\begin{array}{lll}\text { Exact } & \text { Sig. } & (2- \\
\text { sided }) & & \\
\end{array}$ & $\begin{array}{lll}\begin{array}{l}\text { Exact } \\
\text { sided })\end{array} & \text { Sig. } & \text { (1- } \\
\end{array}$ \\
\hline Pearson Chi-Square & 1.754(b) & 1 & .185 & \multirow{6}{*}{.319} & \multirow{6}{*}{.237} \\
\hline Continuity Correction(a) & .597 & 1 & .440 & & \\
\hline Likelihood Ratio & 2.916 & 1 & .088 & & \\
\hline Fisher's Exact Test & & & & & \\
\hline Linear-by-Linear Association & 1.719 & 1 & .190 & & \\
\hline $\mathrm{N}$ of Valid Cases & 50 & & & & \\
\hline
\end{tabular}

There are no significant relations between family support and satisfaction with current rate of profit. One woman may be satisfied on her profit without depending on support of family. Satisfaction on current rate profit depends upon expected profit and complexity of business.

Family Support or Not * Face Obstacle or not Cross-Tabulation
\begin{tabular}{|ll|l|l|l|}
\hline Family support or not & Face obstacle or not & Total \\
\hline & Yes & No & \\
\hline & Yes & 12 & 33 & 45 \\
Total & 4 & 1 & 5 \\
No & 16 & 34 & 50 \\
\hline
\end{tabular}

Table-07: Relation of family support and obstacle.

Table shows reflection of family support on facing any obstacles in doing business. 12 business owners get family support and still face obstacles while 33 don't face obstacles this reveals the importance of family support to women owned business. 


\section{Chi-Square Tests}

\begin{tabular}{|c|c|c|c|c|c|}
\hline & Value & df & $\begin{array}{l}\text { Asymp. Sig. (2- } \\
\text { sided) }\end{array}$ & 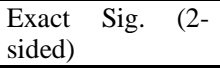 & $\begin{array}{l}\text { Exact Sig. (1- } \\
\text { sided) }\end{array}$ \\
\hline Pearson Chi-Square & $5.882(\mathrm{~b})$ & 1 & .015 & \multirow{7}{*}{.031} & \multirow{7}{*}{.031} \\
\hline Continuity Correction(a) & 3.687 & 1 & .055 & & \\
\hline Likelihood Ratio & 5.491 & 1 & .019 & & \\
\hline Fisher's Exact Test & & & & & \\
\hline Linear-by-Linear & 5.765 & 1 & .016 & & \\
\hline $\begin{array}{l}\text { Association } \\
\mathrm{N} \text { of Valid Cases }\end{array}$ & 50 & & & & \\
\hline $\mathrm{N}$ or valid cases & & & & & \\
\hline
\end{tabular}

Chi square value is 0.015 which is smaller than 0.50 . This means there is strong relation between family support and facing obstacles. When a family support is given to female entrepreneurs then she faces no obstacle which is statistically strongly significant.

\section{Summary Of Major Findings}

Research objective is to find out the cause and solution of the problems confronted. Henceforth it's hereby this research found out the impact of micro financing on women entrepreneurship in Sylhet city. While most of the women are wasting their time at home enjoying watching television just then some enthusiastic women are contributing in family income. This has become easy for having micro-level finance for starting a venture in their own names. Most of the women entrepreneurs are making a profit on their self employment.

There are some major findings which is found to be statistically significant are.

I. The groups of married women in age range of 31-40 years and below graduation constitute the most of the female entrepreneurs in Sylhet City.

II. Level of education is not primary determinants of making profit but women with above graduation earns higher rate of profit.

III. Maximum businesses owned and run by women are sole proprietorship concern.

IV. Semi strong or relative negligible dependency between rate of profit earned by enterprise and source of capital. Saving with loan and family source are the most promising source of finance. Loan as source of capital is not significant. This result mean a negative sign for financial institutions on providing finance to women owned enterprise.

V. Strongly significant relation between start-up capital and rate of profit.

VI. Statistical significant relation between training and rate of profit earned by female owned enterprise.

VII. Insignificant relation between family support and satisfaction with current rate of profit.

VIII. Highly significant relational dependency between family support and facing obstacles.

\section{Recommendation}

Following the summary of major findings, the research would direct to point out some remedial measures to remove the barrier in women entrepreneurship in city. As only one woman is found to use loan as capital and succeeded in making profit. The first point to mention in recommendation is banking and non banking financial institutions should provide better services in women enterprise.

There are some major recommendation those can be drawn from findings are as;

I. Arrangement for training facility on regular basis.

II. Family support can remove social barriers and make the way smooth for women. So family support needs to be widened.

III. Contribution of financial institutions should be exercised in practice.

IV. A separate and specialized information booth for women enterprise should be set up to help every new and existing women entrepreneur.

V. Government patronizations on fostering growth of female entrepreneurs should be widespread.

VI. Others: smooth supply of raw materials, up-to-date information, removing social barrier and most important one is government support are some of the other must mentionable suggestion to promote female entrepreneurship in Sylhet city.

\section{Conclusion}

Realization has gradually dawned on all concerned that a society cannot afford to waste half of its human resources by discrimination on grounds of gender. This increasing awareness on the part of the government has led to the adoption of national policies to facilitate a development process involving women in all spheres particularly in economic activities focusing especially on entrepreneurship development. Women have now become aware of their socio-economic rights and have ventured to avail the opportunities initiated for them. A sustainable economy is a precondition for national growth and prosperity including institutionalization 
of a democratic system. It is also impossible to achieve the target of a poverty-free society without incorporation of women in the mainstream economy. Considering the issue, a special emphasis has been given by the Government, donor agencies, NGOs, business community and all other relevant stakeholders through different interventions to ensure increased women's participation in formal economic sector, especially in business and industry. Despite various initiatives from different corner of the state, the level of participation of women in the mainstream economic activities, especially private sector, remains insufficient and the percentage of women in business and industry is still well below than that of their male counterpart.

\section{References}

[1] Saxena. A., The rise of women entrepreneurship, 2016 available at https://www.entrepreneur.com/article/271784

[2] Female Entrepreneurship Index Press Release, June 18, 2015 available at https://thegedi.org/2015-female-entrepreneurship-indexpress-release/

[3] Begum, R. Entrepreneurship in Small-scale Industry: A Case Study of Engineering Units”, Dhaka University Journal of Business Studies, 14, 1993, 159-162.

[4] Ahmed,. M. U., The Economics of Small-Scale Industries Revisite, 2003, Dhaka, Bangladesh.

[5] Choudhury, M.A., Hossain, S. M., \& Solaiman, M, A well-being model of small-scale microenterprise development to alleviate poverty: A case study of Bangladesh village. International Journal of Sociology \& Social Policy, 28, 2008, (11/12), 485-501.

[6] Habib, Wahidul M., Naheed, N. R., \&Haque T, Factors Affecting Women Entrepreneurship in India: A Multivariate Analysis, Journal of Business Studies, 16 (1), 2005, 249-258.

[7] Chandar,. S \& Arora,. Dr. D.D Study of financial problems of women enterprises, International Journal of Social Sciences \& Interdisciplinary Research, Vol.2 (4)2003, ISSN 2277 3630,

[8] Ibru, C, Growing microfinance through new technologies, Federal University of Technology, Akure, Nigeria, 2009

[9] Lakwo, A, Microfinance, rural livelihood, and women's empowerment in Uganda. African Studies Centre Research Report 85/2006, 2007

[10] Ojo, O. Impact of microfinance on entrepreneurial development: The case of Nigeria. Faculty of Administration and Business, University of Bucharest, Romania, 2009.

[11] Haque, M, Itohara Y, Women Empowerment through Participation in Micro-Credit Programme: A Case Study from Bangladesh, Journal Social Science, 5(3) 2009 pp. 244-250.

[12] Chowdhury, MJA, Microcredit, Enhancement of Entitlement, and Alleviation of Poverty: an Investigation into the Grameen Bank's Role in Bangladesh, Unpublished Ph.D. Dissertation, University of Stirling, UK, 2000.

[13] Afrin, S. Islam, N. Ahmed, SU, A Multivariate Model of Micro Credit and Rural Women Entrepreneurship Development in Bangladesh, International Journal Business Management, 3 (8), 2008 pp. 169-85.

[14] Huda, A Comparative Study of Women Entrepreneurs in Formal and Informal Economy: A Study of Dhaka City, Asian Journal of Business Management 1(1, 2009), 19-23, ISSN: 2041-8752

[15] Nawaz, Faraha. Nexus between Women Entrepreneurship Development and Empowerment: Bangladesh Context. Nepalese Journal of Public and Governance 26(3), 2010: 62 -72.

[16] IDLC monthly Business Review, Volume 10, Issue 7, 2014 available at http://www.idlc.com/business.../Monthly\%20Business\%20Review\%20-\%20Jul... 